University of California, Hastings College of the Law UC Hastings Scholarship Repository

Faculty Scholarship

1994

\title{
Why the Wind Changed: Intellectual Leadership in Western Law
}

Ugo Mattei

UC Hastings College of the Law, matteiu@uchastings.edu

Follow this and additional works at: http://repository.uchastings.edu/faculty_scholarship

Part of the Comparative and Foreign Law Commons, and the Economics Commons

\section{Recommended Citation}

Ugo Mattei, Why the Wind Changed: Intellectual Leadership in Western Law, 42 Am. J. Comp. L. 195 (1994).

Available at: http://repository.uchastings.edu/faculty_scholarship/522

This Article is brought to you for free and open access by UC Hastings Scholarship Repository. It has been accepted for inclusion in Faculty Scholarship

by an authorized administrator of UC Hastings Scholarship Repository. For more information, please contact marcusc@uchastings.edu. 


\section{Faculty Publications \\ UC Hastings College of the Law Library}

Author: Ugo Mattei

Source: $\quad$ American Journal of Comparative Law

Citation: $\quad 42$ Am. J. Comp. L. 195 (1994).

Title: $\quad$ Why the Wind Changed: Intellectual Leadership in Western Law

Originally published in AMERICAN JOURNAL OF COMPARATIVE LAW. This article is reprinted with permission from AMERICAN JOURNAL OF COMPARATIVE LAW and Law School, Univ. of Michigan. 


\section{Comment}

\section{WHY THE WIND CHANGED: INTELLECTUAL LEADERSHIP IN WESTERN LAW}

The Reception of Continental Ideas in the Common Law World, 1820-1920. Edited by Mathias Reimann. Berlin: Duncker \& Humblot, 1993. Pp. 252.

Der Einfluss deutscher Emigranten auf die Rechtsentwicklung IN DEN USA UND IN DEUTSChLAND. Edited by Marcus Lutter, Ernst C. Stiefel, and Michael H. Hoeflich. Tubingen: J.C.B. Mohr, 1993. Pp. xii, 571.

\section{Reviewed by Ugo Mattei*}

\section{INTRODUCTION}

In this essay I will examine legal transplants from the civil law to the common law as described in the books under review, to explore the characteristics that make a legal culture a leader in the international arena. I appreciate the enormous amount of knowledge that comparativists may find in these two books, and try to make a sense of the wealth of data now so easily available. My effort will be like that of an arm chair anthropologist in front of the results of his field research colleagues. My contribution, rather than adding new evidence, will be focused on the understanding of what we have and on what's next.

My main thesis is that there is an inverse relationship between leadership in Western law and the degree of positivism and localism of a given legal culture. Leading legal ideas which influence other systems are those which help to understand the law as a phenomenon

* Ugo Matrei is Alfred and Hanna Fromm Professor of International and Comparative Law, University of California, Hastings College of the Law, San Francisco. Professor of Law, Universita' di Trento.

This paper is dedicated to Alfred and Hanna Fromm - Jewish refugees as are most of the scholars discussed in this essay - who through their generosity made it possible for my family and me to enjoy the experience of being part-time emigres in hopefully better times. I've benefitted, as usual, from the teachings and comments of Mauro Bussami, Antonio Gambaro, James Gordley, Elisabetta Grande, Rodolfo Sacco, P.G. Momateri and Rudolf B. Schlesinger. I wish to thank Jeff Lena and Luisa Antoniolli for editing. 
of social organization and which are not too narrowly limited to the peculiarities of one given legal system. This theory can explain three subsequent leadership roles in Western law - that of France, Germany and the United States - and anticipate possible future developments.

\section{The Development of a Paradigm}

Ten years ago few legal scholars were even aware of "legal transplants" between the common law and the civil law. The theory of legal transplants in the development of the law had already been presented by Alan Watson with his usual clarity, provocativeness and strength: "most changes in most systems are the result of borrowing". 1 But the evidence that he offered was mostly drawn from the civil law world and some earlier research on exchanges between the common law and the civil law was not mentioned. ${ }^{2}$

For many scholars Watson's theory illustrated the same point as a story told me a few years ago by his mentor, David Daube. In front of him one day, at Berkeley, Kelsen asked Freud the secret of success in academia. After a moment the great master of psychoanalysis answered: "Exaggerate!"

Bit by bit, however, the theory of legal transplants conquered new people. Some scholars were not merely observing transplants occurring but started to push the theory forward. By the eighties, legal transplants had become a classic subject of comparative law scholarship. In 1990, the Thirteenth Congress of the International Academy of Comparative Law picked it up as one of its topics. The same happened in 1993 at the Association Henry Capitant.

In France, Eric Agostini ${ }^{3}$ - following the path of Rodiere, 4 Gaudemet ${ }^{5}$ and others ${ }^{6}$ - entitled the second part of his book, The Migration of Legal Systems. Agostini, focusing on Japan and Turkey's importation of the civil law tradition, developed a distinction between assimilation and adaptation in exporting the law, and also distinguished the phenomenon of export from that of import. ${ }^{7}$

In Germany, Reinhard Zimmermann, Reiner Schulze and Elmar Wadle are carrying on an editorial project - the Schriften zur europäischen Recht und Verfassungsgeschichte - in which a number of volumes are devoted to legal transplants within the civil law tradition.

1. Alan Watson, Legal Transplants 94 (1974).

2. Lenhoff, "America's Cultural Contribution to Europe in the Realm of Law," 16 Buffalo L.R. 7 (1964). Id., "America's Legal Inventions Adopted in Other Countries," 1 Buffalo L.R. 118 (1951).

3. "La circulation des modèles juridiques," Rev. Int. Dr. Comp. 461 (1990).

4. "Approche d'un phenomen: les migrations des sistèmes juridiques," in $\mathrm{Me}$ langes Marty 947 (1978).

5. "Les transfers du droit," Année Sociologique 29 (1976).

6. Rivero, "Les phenomenes d'imitation des modèles étrangères en droit administratif," Pages de Doctrine II 458 (1980).

7. Eric Agostini, Droit Compare 243ss (1988). 
In Italy, Rodolfo Sacco - followed by many others - developed the theory of legal transplants in the first edition of his 1980 Introduction to Comparative Law. Most of his evidence concerned transplants within the civil law world, and between civil law and socialist countries. By the fifth edition of that work, Sacco ${ }^{8}$ had developed a sophisticated theory of legal change - based on what he calls "legal formants". This work helped shift the theoretical orientation of comparative law from the static approach of outlining the differences between legal families into a dynamic one in which the relationship between the major legal systems of the world was viewed as a process of constant evolution and change. ${ }^{9}$

In the United States Edward Wise, one of the legal scholars most known for his work on legal transplants, has joined the team of Rudolf Schlesinger in working on the sixth edition of his classic Comparative Law, enriching even more a work traditionally attentive to this particular phenomenon. ${ }^{10}$ James Gordley has also contributed to the tradition, in which the recently deceased great Italian comparativist Gino Gorla had long been active, ${ }^{11}$ by tracing the history of legal transplants in a common European intellectual environment eventually received by the Common law. ${ }^{12}$ In Great Britain many historians and comparativists, from Simpson ${ }^{13}$ to Markesinis, ${ }^{14}$ are now working on this paradigm.

Almost all of the early work on legal transplants (with the possible exception of some of the most historically oriented) focused on transplants from the western legal tradition to countries not belonging to it and desiring to create a "modern" legal system. ${ }^{15}$ Typically the focus was on legal transplants within the civil law (e.g., the recep-

8. Rodolfo Sacco, Introduzione al Diritto comparato $132 \mathrm{ff}$ (V ed. 1992).

9. Sacco, "Legal Formants: A Dynamic Approach to Comparative Law," $37 \mathrm{Am}$. J. Comp. L. $1 \mathrm{ff}$. (1991). A comparative discussion of Sacco's and Watson's work can be found in Ferreri, "Assonanze transoceaniche," Quadrimestre 185 (1993).

10. See the supplement (1994) of Comparative Law by Schlesinger, Baade, Herzog and Wise. Interestingly Edward Wise wrote the piece on the analysis of the Italian Code of Criminal Procedure a major case of transplantation. For his previous work on transplants see Wise, "Legal Tradition as a Limitation on Law Reform," $26 \mathrm{Am}$. J. Comp. L. 14 (supp. 1978). Id., "American National Report, The Transplant of Legal Patterns, XIII Congress of Comparative Law," Am. J. Comp. L. (Supp. 1990).

11. See some of the results of a life-long scholarly enterprise in Gorla \& Moccia, "A Revisiting of the Comparison between Continental Law and English Law (16th19th century)," 2 J. Leg. History 143 (1981).

12. James Gordley, The Philosophical Origins of Modern Contract Doctrine (1991).

13. Simpson, "Innovation in Nineteenth Century Contract Law," 91 L. Q. Rev. (1975).

14. B.S. Markesinis, The Gradual Convergence. Foreign Ideas and English Law on the Eve of the 21st Century (1993).

15. See, for example, Alliot, "L'acculturation juridique," in Etnologie Generale (J. Porier ed. 1968). More literature is cited in Mattei, "Socialist and Non-Socialist Approaches to Land Law. Continuity and Change in Somalia and other African States," 16 Rev. Socialist L. 17 (1990). 
tion of Roman law in Germany), ${ }^{16}$ or within the common law (e.g., the reception of English Law in the colonies).

The effort to identify transplants from the civil law to the common law is much more recent. Before the appearance of the books under review, materials were limited. True, there had been a few classic works on the influence of the civil law in the early years of American law from the early intuition of Herman Oliphant ${ }^{17}$ to Roscoe Pound. ${ }^{18}$ Moreover, some legal historians were aware of the impact of continental legal scholarship on English jurisprudence. ${ }^{19}$ The impact of the civilian thinking at Doctor's Commons on English Law had been studied, ${ }^{20}$ as well as the impact of Roman law on the development of early common law and equity. ${ }^{21}$ It is clear, however, that it is one thing to detect some particular influence at a peculiar historical moment and quite another to reflect on transplants as a phenomenon linking two families of law. ${ }^{22}$

When $I$ addressed the issue, late in the eighties, in a couple of Italian language works deservedly forgotten, I was able to find some early and fairly specific articles by Wittman, La Piana, Herget, Hoeflich, but not much more. ${ }^{23}$ Today, with the two contributions addressed in this review essay, the American Journal of Comparative Law special Issue devoted to the influence of Savigny on American Law, ${ }^{24}$ and other scholarly work, the amount of evidence is becoming impressive. ${ }^{25}$ No longer can scholars trying to understand the western legal tradition pretend that it is divided in two hermetically sealed subtraditions: the common law and the civil law. ${ }^{26}$

16. See James Q. Whitman, The Legacy of Roman Law in the German Romantic Era: Historical Vision and Legal Change (1990).

17. Oliphant, "A Return to Stare Decisis," 14 A.B.A. Journal 75 (1928); see also, for early consciousness, Hoeflich, "John Austin and Joseph Story: Two Nineteenth Century Perspectives on the Utility of the Civil Law for the Common Lawyer," 29 Am. J. Leg. Hist. 36 (1983).

18. Roscoe Pound, The Formative Era of American Law 94 (1950).

19. Stein, "Legal Science During the Last Century: England," Inchieste di Diritto Comparato. La Scienza del Diritto Nell' Ultimo Secolo (M. Rotondi ed. 1976). See also Simpson, supra n. 13.

20. See Brian P. Levack, The Civil Lawyers in England, 1603-1641 (1973); Daniel L. Coquillette, The Civilian Writers at Doctor's Commons (1988).

21. For a brief introduction see William Holdsworth, Some Makers of English Law (1938).

22. Peter Stein noticed that English jurisprudence always had a foreign blend, op. cit. supra n. 19.

23. Tutela Inibitoria e Tutela Risarcitoria (1987); Stare Decisis (1988).

24. 37 Am. J. Comp. L. 1 (1989).

25. See e.g., Mathias Reimann, Historische Schule und Common Law: Die Deutsche Rechtswissenchaft des 19 Jahrhunderts im amerikanischen Rechtsdenken (1993).

26. See Mattei, "Verso una tripartizione non eurocentrica dei sistemi giuridici," in Studi in Memoria di Gino Gorla (forthcoming 1994); Gordley, "Common Law v. Civil Law: Una distinzione che sta scomparendo," in Studi in onore di Rodolfo Sacco (forthcoming 1994); Id., "Common law und civil law: eine uberholte Untersheidung," Z.Eu.P. 498 (1993); Lupoi, "Common Law e Civil Law (alle radici del diritto europeo)," Foro It. 1993, V, 431. 


\section{Leaders and Followers in the Law}

Some colleagues may say that the data collected in these books is not complete. ${ }^{27}$ Mathias Reimann himself has written with remarkable understatement of the relevance of his project, that the influence never reached the deeper or, one might say, "vulgar" layers of the law. ${ }^{28}$ And this observation has been made by others, notably by Watson in his contribution on Chancellor Kent. ${ }^{29}$ To be sure, more field research on this paradigm will be most welcome, as welcome as the moment when we will have a tool to measure the deepness and effectiveness of transplants.

The comparative law community is now facing the problem of understanding why legal transplants happen and whether there are recognizable patterns. This task has been taken on, for example, by the small group of the comparative law and economics scholars organized by Professor Robert Cooter in the Comparative Law and Economics Forum. ${ }^{30}$ Within this group there is a continual effort to explain legal change in terms of economic efficiency. ${ }^{31}$ Of course, efficiency has never been the only force behind transplants. There may be many instances of the opposite. For example, it is by no means clear that the recent adoption of the American style Criminal Procedure in Italy has been an "efficient" choice.

This last major phenomenon of importation of an American inspired solution within a civil law country ${ }^{32}$ as well as the notable attention of other civilian legal cultures to this happening, is only the most recent and indeed impressive device of the phenomenon of import from the United States ${ }^{33}$ that I will try to address. If we take the balance of payments of the civil law versus the common law we can easily see that in the recent years it has turned negative. To put it in a different way, the civil law has recently ceased to be an exporting legal culture and has become an importing one. If this change has indeed, occurred then it is important to ask why.

27. See Zimmermann, Book review of Lutter, Hoeflich, \& Stiefel, Z.Eu.P. (forthcoming 1994).

28. See Reimann, "Patterns of Reception," in The Reception of Continental Ideas in the Common Law World 1920-1920 at 17 (Mathias Reimann ed. 1993).

29. Watson, "Chancellor's Kent's Use of Foreign Law," id. at 45.

30. Professors R. Cooter, D. Rubinfeld, L. Kronhauser, H. Hansmann, T. Ulen, M. Adams, W. Fikentsher, J. Finsinger, G. Hertig, G. Horsmans, U. Mattei and S. Ota.

31. See Mattei, "Efficiency in Legal Transplants. An Essay in Comparative Law and Economics," 14 Int. Rev. Law Econ. 3 (1994). Cooter \& Drexl, Winners and Losers after Maastricht (forthcoming).

32. Pizzi \& Marafioti, "The New Italian Code of Criminal Procedure: The Difficulties of Building an Adversarial Trial System on a Civil Law Foundation," 17 Yale J. Int. L. 1 (1992); Amodio \& Selvaggi, "An Accusatorial System in a Civil Law Country: The 1988 Italian Code of Criminal Procedure," 62 Temple L. R. 1211 (1989).

33. See for a recent contribution in this direction, Wiegand, "The Reception of American Law in Europe," 39 Am. J. Comp. L. 229 (1991). 


\section{Winds of Change: From France to Germany}

The reception of continental ideas in the common law world in the period analyzed by Reimann's project is a central event in the expansion of the civil law tradition in the world. It also shows the leadership within the civil law tradition of two sub-traditions: the French and the German. ${ }^{34}$

The influence and the relationship between these two legal systems has never been static. The timing and the means by which the influence has been exercised is also very different. The hundred years studied by Reimann's taskforce can roughly be divided into two half centuries. The first half was dominated by the French model and the second half by the German. Indeed, we should not make the mistake of linking this fact to the later enactment of the BGB (1900) than the Napoleonic Code (1804). Only French law had the code as a vehicle of exportation. German law was principally exported by means of another "legal formant": 35 the work of scholars. Indeed, as we will see later on, by the 1920 's, shortly after the enactment of the BGB, the influence of German law was already in sharp decline. By the beginning of the period discussed in Lutter-Stiefel-Hoeflich's project, German law was yielding its world leadership to American law. As the Lutter-Stiefel-Hoeflich's book shows, the influence of the exceptional generation of refugee scholars - some of whom are still very active - was by no means limited to the country which rescued them. Indeed, their role as exporters of civil law ideas to America is in my opinion overshadowed by the feed-back they contributed to the civil law itself - or by their pivotal role as framers of a modern transnational Western law in which the traditional barriers between the common law and the civil law are slowly eroded because of transplants.

It may well be the case that in the future we will see a blossoming of this transnational western law. If so, the importance of the German refugee scholars will be difficult to overstate. With the bitter irony once used by Rudolf Schlesinger in commemorating Fulda, we will have to acknowledge an incomparable gift of Adolph Hitler to the rule of law that he defiled during his dictatorship. ${ }^{36}$

Until that moment, however, the student of legal transplants has to tell a story of successive world leadership by particular legal systems both within and beyond the western world.

Of course, to discuss changes in legal leadership, we should explain what we mean by a leading legal system. The least pretentious

34. This leadership is noticed by Schlesinger in his Comparative Law, which speaks of "paradigmatic experiences" in civil law. The same is done by Sacco in his Introduzione which speaks of "noticeable models" in the Romanist area.

35. This expression is used in the sense discussed in Sacco, supra n. 9.

36. See Schlesinger, "A Tribute to Carl H. Fulda 1909-1975," 11 Texas Int. Law J. 401 (1976). On Fulda see also the excellent contribution by Baade, "Karl Fulda," in Der Einfluss deutscher Emigranten auf die Rechtsentwicklung in den USA und in Deutschland at 57 (Marcus Lutter, Ernst C. Stiefel \& Michael H. Hoeflich eds. 1993)[hereinafter Lutter]. 
test of leadership is the capacity of a legal system or of some of its products (codes, pieces of legislation, legal institutions, scholarly writings. . .) to exert influence not only within closely related legal systems but also outside of them. A system can be considered leading whenever it is - wholly or in part - considered, discussed, copied or adopted in a larger number of other systems than any other legal system at that historical moment.

To be sure, an Italian scholar is tempted to begin the story with the time of Bologna, but this, of course, would be beyond the scope of the present review.

In the years in which the French influence was reaching the common law - by the different and very interesting patterns described by Hoeflich, ${ }^{37}$ Watson ${ }^{38}$ and Clark, ${ }^{39}$ - the export of the Napoleonic Code was impressive throughout the world. True, in some parts of it - and the Louisiana experience is most revealing - there was competition from the Spanish tradition. But to be sure the expansive power of the French code is staggering. Just to give a few examples: it was introduced in Belgium; it was copied by the Dutch Code of 1838 and it influenced both the Italian pre-unity Codes, and the post-unity Code of 1865. It was adopted in Poland. It has deeply influenced the Russian Zwod Zakonov of 1832, the Turkish Mecelle (1869) and the Rumenian Kodul Civil. Various Swiss cantons and German States before the Swiss and German Codifications enacted the Code Napoleon. It reached Louisiana and - if it is true that even the Spanish Code of 1889 is very much indebted to the French model - it influenced many Latin American countries. As has been pointed out, "if we look at its imitations the French statutory law is leading within the civil law." 40

It is striking that - with the possible exception of Belgium, where the French Code was introduced manu militari by Napoleon himself - the rest of the expansion just described had nothing to do with power and imposition. The French code was admired and voluntarily copied abroad. This is a very important point to bear in mind in the following discussion. English law also enjoyed a worldwide expansion, but this has always been linked to its colonial adventures. Indeed we may say that English law circulated ratione imperii and not imperio rationis even if, of course, it remained influential after decolonization in the former colonies. However, what we are discussing here is the worldwide intellectual leadership of a system of law. This has never been the case with English law.

The papers discussed in the first part of Reimann's book show the leadership of French law. Although arguably in a superficial way, its expansion reached also that part of the Western legal tradition

37. Hoeflich, "Roman and Civil Law in the Anglo-American World Before 1850: Lieber, Legaré and Walker, Roman Lawyers in the Old South," supra n. 28, at 19.

38. See supra n. 28.

39. Clark, "The Civil Law Influence on David Dudley Field's Code of Civil Procedure," supra n. 28 , at 63 .

40. Sacco, supra n. 9, at 226. 
most difficult to influence because of the great wall that divides it into civil law and common law. This French influence on the common law was not, however, via the code but via the legal culture in a broader sense.

No other piece of legislation in modern times has ever enjoyed the same degree of international success. Certainly not by the German BGB, which never circulated. However, the fact that the French were the most important exporters of statutory provisions did not mean that they remained the unchallenged leaders in the export of law. True, the Napoleonic Code has enjoyed quite recent successes the Egyptian Code (1949), itself extensively copied in the Middle East and in Africa being the most important example. But by the half of the period covered by Reimann's book the leadership had already shifted. Indeed most of the world, including the common law was admiring the imposing achievements of the German Pandetists. Scholars from all around the world - including such leading common lawyers as Pollock and Maitland - considered themselves disciples of Savigny. ${ }^{41}$ The contributions by Herget, ${ }^{42}$ Riesenfeld, ${ }^{43}$ Buxbaum, ${ }^{44}$ Reimann, ${ }^{45}$ Whitman ${ }^{46}$ and Graziadei ${ }^{47}$ demonstrate that the influence in England and the United States was far from superficial but reached deep and long lasting layers of the law. Indeed it affected the very conception of the law, or its "image" as Graziadei calls it thus showing how much more important in understanding transplants is to hunt for cultural connections rather than for enacted rules of law. 48 German law also influenced some of the very legal institutions of developing capitalism (Buxbaum, Riesenfeld, Witman). Last but not least, Reimann in his outstanding paper shows us the German influence on the crucial cultural aspect of the academic organization, without however pointing out how this has been the very embrion - or maybe indeed even the cause - of the next change of leadership: from Germany to the U.S.A. 49

The extensive influence of the German model on the common law, which thus far has been too much neglected in the standard comparative law literature, is particularly strong evidence of true intel-

41. See Hoeflich, "Savigny and his Anglo-American Disciples," 37 Am. J. Comp. L. 17 (1989).

42. Herget, "The Influence of German Thought on American Jurisprudence, 18801918 ," supra n. 28 , at 203.

43. Riesenfeld, "The Impact of German Legal Ideas and Institutions on Legal Thought and Institutions in the United States," supra n. 28, at 89.

44. Buxbaum, "The Provenance of No Par Stock: A Comparative History," supra n. 28 , at 99 .

45. Reimann, "A Career in Itself - The German Professorate as a Model of American Legal Academica," supra n. 28, at 165.

46. Whitman, "Early German Corporatism in America: Limits of the Social in the Land of Economics," supra n. 28, at 229.

47. Graziadei, "Changing Images of the Law in XIX Century English Legal Thought (The Continental Impulse)," supra n. 28, at 115.

48. Id. at 115 is probably the most impressive paper for scholarly effort and marshalling of new evidence. It could have been much more assertive in its conclusions.

49. Reimann, "A Career in Itself-The German Professorate as a Model for American Legal Academica," supra n. 28, at 165. 
lectual leadership if we consider that, (with the limited exception of Joseph Story in conflict of law) Anglo-American law was totally neglected in the civil law world. ${ }^{50}$ Everywhere, in the common law, in the civil law and even in non western legal systems "the German systematic and dogmatic method and the concepts defined within it were spreading triumphantly". ${ }^{61}$

Within the civil law world only France, Belgium, Quebec and Louisiana remained relatively unaffected by such expansion. Jurists from Switzerland, Austria, Scandinavia, Russia, Hungary, Rumania, Bulgaria, Italy, Spain and Greece were at work using the German formalistic approach to interpret and discuss their legislation even in the cases in which it was French inspired. Outside of Europe, in most Latin American countries and all the way to China and Japan, German scholarship became the most prestigious source of law. In the Common law world, basic introductions to English law such as that of Geldart or of Jenks employed the typical German terminology to analyze common law structures. The methodological analogies with Langdell's formalism are too striking not to be noticed.52 Reimann's group contribution makes it even more likely that these were not mere methodological reinventions of the wheel.

There was not much that French legal culture could oppose to such an expansion. The approach of the French exegetic school seemed too primitive to be taken seriously. Within scholarly communities there was a desire for legal science that could by no means be satisfied by the black letter approach. ${ }^{53}$ To be sure, individual French authors - from Geny to Duguit - could still become famous and a few marginal jurisdictions remained faithful to the French intellectual leadership. But the personal charisma of a scholar is one thing, the recognized world leadership of a country's legal culture is another thing entirely.

\section{Winds of Change: From Europe to the United States}

It is not easy for a country to acquire intellectual leadership in the law. And once gained it is easily lost. The fall of German prestige was even faster than its rise. An interesting example in the civil law can be found in Scandinavia where antiformalistic legal realism did not allow much formalist thought to survive at all. ${ }^{54}$ In Italy, by the thirties, scholars - at least in the leading field of private law -

50. It is very well known that Savigny cited Story on Conflict of Law. However we must consider that, at the time, Conflicts was a very new area of the law, whose cultural importance was much more marginal than today.

51. Sacco, supra n. 9 , at 240.

52. For further discussion and some examples see Mattei, supra n. 23 and id., Common Law 279 ff. (1992).

53. Compare Hoeflich, "Law and Geometry: Legal Science from Leibnitz to Langdell," $30 \mathrm{Am}$. J. Leg. Hist. 95 (1986). See also the contributions by Graziadei and by Reimann to the Reimann project.

54. Stronholm, "La Philosophie du droit Scandinave," 5 ss. RIDC (1980). Some flavor of the so called Scandinavian realism may be felt by reading many of the contribution that appear on the English language journal Scandinavian Studies in Law. 
were already unsatisfied with German imports and were trying to work out their own solutions. It is interesting to note how in both these contexts the influence of German post formalistic efforts was much more modest than that of its predecessors.

By the end of the period examined by Reimann's group, the prestige of Germany was declining fast, and the world was looking for new intellectual leadership. It is certainly true, however, that until the end of the Second World War - despite the political nadir of German image for decent scholars - the balance of payments betwèen the civil law and the common law still favored the civil law. American legal realism and certainly Dean Pound, one of the scholars most involved in its birth, was still an avid importer. More evidence can be found in the contributions of Thomas Raiser on Herman Kantorowicz, ${ }^{55}$ of Peter Herzog ${ }^{56}$ and Walter-Jabloner ${ }^{57}$ on Hans Kelsen and, to be sure, in most of the papers on those refugee - like Rabels $^{58}$ for example - who were already established jurists in their respective countries. A lawyer of course always maintains the imprinting received during his first year of legal study even if - as the papers on Friz Kessler make clear ${ }^{59}$ - he or she may try to hide it for political reasons. Moreover, for this same reason, since a law teacher shares the minds of thousands of future lawyers, the very fact that they are exposed to his teaching influence the legal system to which they belong. It is no surprise that this point is made in the contributions of Watson on Daube ${ }^{60}$ and of Nörr ${ }^{61}$ and Pennington ${ }^{62}$ on Kuttner - authors who appear not to have influenced positive law at all but who allow us to ask ourselves what is the influence of a scholar. I will address this point later. ${ }^{63}$

Despite the influence of some of the refugee scholars on American law, and particularly the well documented influence of German scholarship on Llewellyn and the U.C.C., ${ }^{64}$ it would be wrong to as-

55. Raiser, "Herman Ulrich Kantorowicz," in Lutter, supra n. 36, at 365.

56. Herzog, "The Enduring Significance of Hans Kelsen," in Lutter, supra n. 36, at 201 .

57. Walter \& Jabloner, "Hans Kelsen (1881-1973): Leben-Werk-Wirkung," in Lutter, supra $\mathrm{n} .36$.

58. See Clark, "The Influence of Ernst Rabel on American Law," in Lutter, supra n. 36, at 107. Kegel, "Ernst Rabel," id. at 277.

59. Particularly, Joerges, "Geschichte als Nicht-Geschichte: Unterschiede und Ungleichzeitigkeiten zwischen Friedrich Kessler und der deutschen Rechtswissenschaft," in Lutter, supra n. 36, at 221; see also Kondgen, "Friedrich Kessler-Ein Grenzganger zwischen den Disciplinen," id. at 287; Sandrock, "Friedrich Kessler und das anglo-amerikanische Vertragsrecht," id. at 475.

60. Watson, "David Daube," in Lutter, supra n. 36, at 549.

61. Nörr, "Stephan Kuttner," in Lutter, supra n. 36, at 343.

62. Pennington, "Stephan Kuttner-Wissenschaft im Zeichen dreier Kulturen," in Lutter, supra n. 36 , at 361.

63. See the brilliant analysis of Dan Cohen, "Listeners and Eavesdroppers: Substantive Legal Theory and Its Audience," 63 Colo. L. R. 569 (1992) who challenges the common assumption that a legal scholar's task is to "persuade" institutional decision makers.

64. See Whitmans, "Commercial Law and the American Volk. A Note on Llewellyn German Sources of the U.C.C.," 97 Yale L. J. 156 (1987). 
sume that the reaction of American Legal Realism to legal formalism has been merely another cultural transplant from Germany. ${ }^{65}$ The truth is - as it is pointed out in Riesenfeld's piece on Roosevelt's America - that by the thirties the seeds of a new world leadership in the law were already evident in a number of peculiar and appealing features of American law. ${ }^{66}$ Rudolf Schlesinger in his "recollections" points out how many positive institutional and cultural factors were already present in the U.S. legal system when he arrived in America (e.g., democratic participation in legal decision making; graduate school of law). ${ }^{67}$ It is no surprise therefore that legal realism - a scholarly product reflecting these particular factors - has been able to contribute to the enterprise of understanding the law as a general phenomenon of social organization.

From that moment, within the western world the wind shifted again. In many areas of the law - also thanks to the feed back effect of the refugee scholars - attention worldwide was directed towards Americans much more than to Germans. ${ }^{68}$ For the first time in the history of western scholarship the "balance of payments" of the civil law tradition became negative. This is a remarkable change since we are told that the civil law is the world of scholars while the common law is the world of judges. ${ }^{69}$ Some scholars from America - e.g., Corbin and Hohfeld - became oracles of the law not only at home but also abroad. Some of their names - as before with the civilians Pothier or Savigny - became part of everybody's legal heritage and not only that of America or of the common law. Some of these names - like Kelsen, ${ }^{70}$ Kessler, ${ }^{71}$ Riesenfeld, ${ }^{72}$ Freund, ${ }^{73}$ Kirkhaimer, ${ }^{74}$ Schlesinger, ${ }^{75}$ Daube, ${ }^{76}$ Kuttner $^{77}$ are to be found among the refugee scholars studied in the Lutter-Stiefel-Hoeflich book.

This, indeed, is a chapter of comparative law yet to be written. Maybe we are still too much involved in its unfolding to be able to study it historically with the necessary detachment. However it

65. See Herget \& Wallace, "The German Free Law Movement as the Source of American Legal Realism," 73 Va. L. R. 399 (1987).

66. I discuss peculiarities of the American Style at the eve of Realism in my Stare Decisis (1988). Style is here used in the sense made clear by John Merryman in his numerous contributions to the knowledge of the civil law tradition.

67. Schlesinger, "Recollections of a Migrant Lawyer," in Lutter, supra n. 36, at 487.

68. The paper by Sturner, "Kurt Hans Nadelmann und Stefan Riesenfeld und ihr Einfluss auf das deutsche und europäische Insolvenzrecht," id. at 493 is for example focused only on the feed back effect.

69. See between many, John P. Dawson, The Oracles of the Law (1968).

70. See supra nn. 56, 57.

71. See supra n. 59.

72. See supra n. 68 and Bolgár, "Albert A.Ehrenzweig-Kurt H. NadelmannStefan A. Rieisenfeld," id. at 95.

73. Reitz, "The Influence of Erns Freund on American Law," id. at 423.

74. Artz, "Otto Kirchheimer: Critic of the Administration of Justice", id. at 33.

75. Kötz, "Rudolf B. Schlesinger," id. at 301; Juenger, "Schlesinger's Influence on the Development of American Law," id. at 225.

76. See supra n. 60 .

77. See supra n. 61 . 
seems clear that the European scholarly community looked increasingly to America in recent years. American paradigms of research, from the "law in the books"-"law in action" distinction (so much connected to legal realism) to law and economics, and to the "common core" approach, are now used everywhere in Europe - Germany included. Recent codifications from the Italian Code of Criminal Procedure $^{78}$ to the Dutch Civil Code ${ }^{79}$ do reveal what has been called the "decivilization of the civil law".80 The style of American legal education is spreading: casebooks are now published in civil law countries as well as in England; endowed published lectures appear as a style of legal literature; ${ }^{81}$ student edited law reviews are cropping up;82 Lexis is becoming a familiar tool in Europe. Even traditional American-style thank you notes can be found at the beginning of civilian law review articles. The prestige of American law has become a powerful reason for the diffusion of Common law ideas in the civil law. Trust - traditionally studied in civil law and today massively imported - is a major example. ${ }^{83}$ Dissenting judicial opinions - so thoroughly studied by Nadelmann ${ }^{84}$ - have been introduced in some European Constitutional Courts and in the European Court of Human Rights. This manner of holding judges accountable for their decisions may represent another positive influence of the common law. ${ }^{85}$

If we look at translations as evidence of influence we find that leading american authors are published with great frequency in other languages. Of course this happens to selected civilians too. But what is remarkable is that since the diffusion of English as a scholarly language is tremendous, translations from English are less necessary than translations into English and from other languages. The shift in leadership is easy to see in Italy, an importing country in modern times, where the number of legal pieces translated from German or

78. See supra n. 31.

79. See, for more influences, Tokyo International Center for Comparative Law and Politics, Dutch and Japanese Laws Compared (1993).

80. See Legrand, "Civil Law Codification in Quebec: A Case of Decivilianization," Z.Eu.P. 575 (1993).

81. The Italian Cardozo Lectures in Law are an example.

82. The Dutch Tilburg International and Comparative Law Review is opening a path and challenging the idea that only graduate students can edit law journals.

83. Christian De Wulf, The Trust and Corresponding Institutions in the Civil Law (1965); Fratcher, "Trust," International Encyclopedia of Comparative Law, VI Ch. 11, $84 \mathrm{ff}$; Gambaro, "Problemi in materia di riconoscimento degli effetti del Trust nei paesi di Civil Law," Rivista Diritto Civile 1984, 1, 93 ss.; Felix Weiser, Trusts on the Continent of Europe (1936). Hein Kötz, Trust und Treuhand (1963); Gambaro, "Trust e competizione fra modelli giuridici," in Studi in onore di Rodolfo Sacco (forthcoming); Hansmann \& Mattei, "Comparative Law and Economics of Trust," (discussion paper for Comparative Law and Economics Forum); Frans Sonnevaldt \& Harrie Van Mens, The Trust: Bridge or Abyss Between Common Law and Civil Law Jurisdictions (1992).

84. See Bolgàr, supra n. 72.

85. For comparative references, Schlesinger, Baade, Damaska \& Herzog, Comparative Law 449-453 V (1988); Graziadei \& Mattei, "Judicial Responsibility in Italy: A New Statute," 38 Am. J. Comp. L. 103 (1990). 
French is today a fraction of what is translated from English. ${ }^{86}$ But it is observable very clearly in other legal systems too. In Israel, for example, the initial imprint of English common law influence was strong. The Common Law influence was then diminished by the impact of civil law scholars, but has been reaffirmed today by the impact of American law. ${ }^{87}$ In Japan, the influence of American scholarship today is so clear that it hardly needs to be discussed. In Latin America today, American law is probably the leading influence too, due to the significant number of legal scholars that study in the United States. ${ }^{88}$ In Eastern Europe, the privatization process is in large part directed by American experts, ${ }^{89}$ and even China is the focus of an effort to establish the rule of law - or maybe - to assert cultural leadership. ${ }^{90}$ It is interesting to note that this tremendous impact is mainly achieved through academic channels by exposing future generations of lawyers to the teaching in American law schools and then sending them back to influence their colleagues. ${ }^{91}$ It would be too simple to say that behind this success there is merely a policy of helping foreign and particularly non western students to get American legal education. Italian, French or Japanese students flocking to the United States would have had the same possibilities to study in Germany or elsewhere, since they do not get much financial aid from American schools or institutions, but they choose not to study in these other countries. They choose instead American schools because they find it more interesting. Their choice is in part influenced by a broader cultural phenomenon that makes whatever is American more appealing to youngsters. This is true in the domain of fashion, of music, and eventually of law: they feel the leadership.

Of course the above is hardly an exhaustive list of the different "patterns of reception", to use Reimann's terminology. Nevertheless it is sufficient evidence that a change of intellectual leadership took place. This shift needs to be studied by the comparative law community.

This change of international academic leadership is likely to be a consequence of that change of leadership - noticed by Max Rheinstein $^{92}$ and discussed by Mary Ann Glendon ${ }^{93}$ - from judges to

86. In the leading collection of legal translations in Italian, that edited by Cosimo Marco Mazzoni and Vincenzo Varano, where the stressed policy is that of pluralism, out of seventeen books so far translated eleven titles are from English.

87. Daniel Friedman, The Effect of Foreign Law on the Law of Israel (1975).

88. See references in Schlesinger, supra $n$. 85, at 316 .

89. See for some updating the "Symposium on Privatization," Hastings Int. \& Comp. L. R. (forthcoming); Schlesinger, Baade, Herzog \& Wise, supra n. 10; Giannaria Ajani, Fonti e modelli nel diritto dell' europa orientale (1993).

90. See Frankel, "Transfers of Knowledge. Statutory Drafting in China," (discussion paper cited by permission of the author).

91. See Trakman, "The Need for Legal Training in International Comparative and Foreign Law: Foreign Lawyers at American Law Schools," $27 \mathrm{~J}$. Legal Education 509 (1975). The kind of visa which is supplied to such students and scholars, is subject to the so called two years rule according to which the foreign scholar once back must physically stay in her country two years before being allowed to come back.

92. Rheinstein, "Leader Groups in American Law," 38 U. of Chi. L. R. 687 (1971). 
scholars within American law. If it is true, as it has been pointed out, 94 that legal scholarship is the least inherently parochial of "legal formants $\$ 95$ and is therefore the most efficient means to diffuse legal ideas abroad, ${ }^{96}$ than it is likely that, as in international politics, leadership at home is a prerequisite for leadership in foreign affairs. It is more likely, in other words, that foreign scholars become interested in the legal culture of a given country when they are persuaded that this culture plays a leading role in shaping a legal system which they admire. The reason may be the practical aspect of legal scholarship, which makes people wrongly believe - as Mary Ann Glendon points out - that the impact and influence of a scholar should be measured in terms of their impact on positive law. ${ }^{97}$ Of course if that were the case we than would consider Bridget Bodenheimer's work ${ }^{98}$ (who helped framing the statute who stopped forum shopping in children's custody disputes) more influential on American law than Max Rheinstain's, 99 Albert Ehrenzweig's'100 or Hans Kelsen's'101 just because these three scholars never directly influenced enactments or court decisions. We should then consider Riesenfeld's contribution to Hawaii retirement law more important and influential than his work on European Law; ${ }^{102}$ or Schlesinger's contribution to New York civil procedure more important than his seminal "common core" project or his Comparative law book. ${ }^{103}$ From a global perspective this is manifestly not the case.

On the other hand, the practical dimension of law, once its limited province is recognized can not be disregarded. And whether one likes it or not the feeling of the lack of relevance of a given legal culture within its own local boundaries may well foreclose its chances to

93. Glendon, "The Influence of Max Rheinstein on American Law," in Lutter, supra n. 36, at 171 .

94. See Monateri, "Legal Doctrine as a Source of Law. A Transnational Factor and a Historical Paradox," Italian National Reports XIIth International Congress of Comparative Law (1986).

95. See supra n. 10

96. See Mattei \& Pulitini, "A Competitive Model of Legal Rules," in The Competitive State (Albert Breton, Gianluigi Galeotti, Salmon \& Ronald Wintrobe eds. 1990).

97. See supra n. 63. 309.

98. See Krause, "American Family Law and Brigitte Marianne Bodenheimer,"

99. Two contributions on this author indeed point out at his tremendous cultural and methodological impact shown inter alia by his being one of the founding fathers of sociology of law. See Glendon, supra n. 93 and von Marshall, "Max Rheinstein," in Lutter, supra n. 36, at 333.

100. See Reimann, supra n. 28 showing a relatively minor role in conflict of law; For a more comprehensive analysis of his work however Kessler, "Gedanken bei Lekture von Albert A. Ehrenzweig's 'Psychoanalytische Rechtswissenshaft'," id. at 281; and Bolgár, supra n. 72 shows his major role as a trait d'union between the lively Austrian culture and paradigms of jurisprudence.

101. See supra nn. 56, 57.

102. See Bolgár, supra n. 72; Sturner, supra n. 68.

103. On the former contribution focuses Juenger, supra n. 75. An excellent appraisal of his cultural impact can be found in Kötz, supra n. 75. Schlesinger's 'common core" book is probably the most widely reviewed product of American culture abroad. 
acquire worldwide leadership. For this reason English legal scholarship, although it belongs to a cultural, political and legal tradition immensely admired abroad, has never been able to assume world leadership. Interestingly, Max Rheinstein himself noticed how American law was becoming more like German law because scholars were assuming leadership within it. ${ }^{104}$

In the remaining part of this review essay I will try to give a sense of the role of the refugee scholars in this change of leadership and to advance some explanations of why the change happened.

\section{Reasons for the Change: Political Atmosphere and the Role of Refugee Scholars}

A few points stand out in a number of the essays. People who escaped the horrors of the destruction of the rule of law in Nazi Europe could not have been expected to be very enthusiastic about European legal systems. This is yet another consequence of the strict relationship between law and politics. As Langbein points out in his paper, something wrong appeared to have been in European legal systems if the destruction of the rule of law and of individual rights was such an easy task for Hitler. ${ }^{105}$

This observation provides us a first explanation for the change of leadership within the Western legal tradition, a political one. There may be a preference in the Western legal culture for solutions which guarantee or appear to guarantee individual rights. ${ }^{106}$ The preference may have facilitated the change of leadership even if it is not a sufficient explanation because it does not tell us why American and not English law took the lead. ${ }^{107}$

Immediately after the First World War the political prestige of Germany fell dramatically. Raiser points out that as early as 1924, even the influential Roscoe Pound encountered such resistance from his fellow faculty that he was unable to invite Herman Kantorowicz to lecture at Harvard just because he was a German.

Western lawyers are usually very fond of the rule of law - the source of their own power - and are always prepared to defend it even against modernization, efficiency or even democracy. The best historical evidence of this point appears at the very birth of the rule of law. It is sufficient to look at the mythology that English legal historians have created around the figure of Sir Edward Coke. The successful alliance of the Common Law Courts with Parliament against the Tudors, was the victory of the old feudal society against very reasonable attempts carried on by Henry VIII and Elizabeth I to modernize the legal system by means of equity and of the other prerogative courts. The victory is considered the birthdate of the

104. See Rheinstein, supra n. 92.

105. Langbein, "The Influence of German Emigrés on American Law: The Curious Case of Civil and Criminal Procedure," in Lutter, supra n. 36, at 321.

106. This seems to me the main force behind the import of American Criminal Procedure in Italy.

107. See, infra $101 \mathrm{~g} f f$. 
"western style" rule of law. The seventeenth century English Parliament had, of course, nothing to do with democracy. Nevertheless, this victory has been depicted in the leading English Whig historiography - accepted in much comparative literature - as a triumph of individual rights and of a modern conception of law. The reality was the opposite, ${ }^{108}$ but such propaganda has been enough to officially obliterate the role of the civilian writers in modernizing the common law. 109

It is only natural that common law systems were highly regarded by civil lawyers during post War reconstruction, especially American law where Edward Coke's conception of the rule of law as superior to political will became positive law in Marbury v. Madison. After all, the two common law systems were on the right side, and moreover had won the war. To be sure, in the post war period some American conceptions of law were imposed on others (Japan offers the clearest example). But, due to the average professional lawyer's love for the rule of law, the reception thereafter was very much also the product of choice. ${ }^{110}$

One of the most interesting examples of fervent admiration, mixed of course with a lot of well deserved gratitude, can be found in the work of Lenhoff discussed by Junker.111 As has been pointed out, "No history of the two legal systems can be written now without taking into account how men like Dr. Lenhof brought back into the civil law the great currents of Anglo-American legal and political ideas". ${ }^{112}$ In two relatively early papers, Lenhoff gives us such a strong picture of the role of American law in the development of the civilized world that even the most fervent admirer of American law may find it overemphasized. ${ }^{113}$ This attitude again is only natural and it is by no means linked only to politeness and gratitude. It sheds light on the role of immigrants scholars as legal brokers - or, as it has been said, as "fertilizers" of American law. ${ }^{114}$ Indeed, the pattern of import and export can usually be described as one in which the import from the civil law happened sotto voce, while the export was very open and passionate. We can find other examples in such a pat-

108. See Frederic W. Maitland, English Law and the Renaissance 3 ff. (1901).

109. See Levack, supra n. 20.

110. "The military victory of English and American democracies over Nazi Germany and Japan has produced and irresistibly diffused two fundamentally important data. From one point of view it has shown that English and American institutions are efficient and therefore apt to carry on progress. On the other hand it has shown that the same institutions were better than the European counterparts to protect liberal and democratic values." Sacco, supra n. 9, at 250.

111. See Junker, "Der Einfluss von Arthur Lenhoff (1884-1965) auf das Arbeitsrecht im deutschsprachigen Raum," id. at 267.

112. Touster, "Reflections on the Emigre' Scholar: In Memory of Arthur Lenhoff," 16 Buffalo L. R. 1 (1966) p. 4.

113. See Lenhoff, supra n. 2.

114. Such expression is used in the report by Davie, Refugees in America, Report of the committee for the study of recent immigration from Europe 287-99 (1947). 
tern, Kronstein - interestingly discussed by Gerber - being the most clear due to the strong political nature of antitrust law.115

Of course this pattern was not the only one possible, but traces of it are at play everywhere. To be sure Otto Kirchhaimer in his book on Political Justice scandalized whomever was not equipped to understand his very sophisticated message. This author subtly compared some distortions of the American criminal process with Stalin's Russia or with Nazi Germany. But, as Donna Artz points out in her excellent paper, ${ }^{116}$ the book appeared later, and Kirchhaimer has always been careful to use two levels of communication, a conservative one for lawyers, and a more open one for his political science readership. Kirkhheimer's contributions on Criminal law are an interesting example of careful insights from a civil law perspective, offered to common law lawyers who actually did not need them at all.117

The immigrants who were most able to criticize American law openly even in "political" areas have been those who passed through a new legal education and therefore had the feeling of being insiders in the American system. Rudolf Schlesinger's essay on comparative criminal procedure is probably the best example. ${ }^{118}$ However, even here - and its author's contribution to the volume discussed is the best evidence - the described pattern is not completely absent. Indeed the visibility and impact in Europe of the work of Schlesinger as an American scholar are much more important than those of works in which he criticizes American positive law. The very idea of the factual approach of Cornell's seminars, as well as that of a Case book in Comparative law could not have been conceived outside of the United States. Indeed, the admiration for such an American inspired approach to scholarship have been immense and the few - and indeed a little chauvinistic - criticisms from civilian reviewers have been focused on Schlesinger being too much of a common lawyer. ${ }^{119}$ Again the influence of the civilian scholar has been sotto voce, while his impact as a common lawyer have been immense. Other examples of this pattern, conscious or unconscious, can be found in the essay on Homburger. ${ }^{120}$ and in those on Kessler. ${ }^{121}$

115. Gerber, "Heinrich Kronstein and the Development of United States Antitrust Law," in Lutter, supra n. 36, at 155; On the same author Rhebinder, "Heinrich Kronstein: Sein Einfluss auf das deutsche Rechtsdanken und die Fortentwicklung des deutschen Rechts," id. at 383. A deep influence on American Antitrust has been exercised also by Callmans discussed in the book by Baums, id. at 63 .

116. Supra n. 74. See also Teubner, "Man schritt auf allen Gebieten zur Verrechtlichung: Rechtssoziologische Theorie im Werk Otto Kirchheimers," in Lutter, supra n. 36 , at 505 .

117. The different paths used by common lawyers and civilians to guarantee defendant's rights are discussed, in the field approached by Kircheimer, in Elisabetta Grande, Accordo Criminoso e Conspiracy (1993).

118. See "Comparative Criminal Procedure: A Plea for Utilizing Foreign Experience," 26 Buffalo L. R. 361 (1977).

119. Such a critique was advanced in a book review by $D$. Tallon.

120. See Fisch, "Adolf Homburger (1905-78)," in Lutter, supra n. 36, at 145.

121. See supra n. 59. 
This pattern of influence can be seen as the most advanced mixture between the past experience and the future challenges that could happen to immigrant scholars in the domain of the law due to the peculiar link between law and politics. This link, clearly stressed by the positivistic approach, puts legal scholars in an odd situation if compared to scholars of other disciplines. Many of the essays in the book are evidence of this point. Certain migrant scholars - indeed intellectual giants - have been relegated to less prestigious Universities. ${ }^{122}$ Others - and Rabels is surely the most startling example - never received an American Chair. ${ }^{123}$ The ones who found their way to the top of the academic system, occupying chairs in places such as Yale, Chicago, Berkeley, Columbia or Cornell are again those who passed through a second formal legal education, or those who for professional reasons were already experts in American law. This is another paradox of legal scholarship in the era of legal positivism. It is caught between its practical dimension (its link with politics) and the parochialism that seems to be part of the very ideology of our discipline. Indeed, in legal discourse we always find at play, usually randomly mixed, what Homburger maintained as clearly distinct: the analytical and the creative function of the scholar. ${ }^{124}$ If in the former the positivistic dimension does not preclude scholarship, in the latter, "normative" dimension, its impact is very evident. Paradoxically, even if a scholar's authority should rest only on his scholarship, his "belonging" to the system may make a difference. So, an Italian or an American law professor, even if she is the world's foremost expert on the organization of courts, may be very reluctant to criticize how the French Conseil Constitutionnel is organized. She will be even more reluctant to advance a proposal for its reform unless expressly demanded by someone else, preferably a French colleague. The same law professor, even if ignorant, about for example local government, may not feel at all reluctant to write a very strong case note criticizing a decision of "her" Supreme Court. This paradox, which may help explain the attitude of refugee legal scholars, is due to the impact of legal positivism on the very perception of the role of legal scholarship. ${ }^{125}$ This approach forecloses legal scholars from considering themselves as actors of one common enterprize - that, for example, of designing better organized courts. On the contrary, scholars themselves feel the need of a sort of local political legitimization in trying to "persuade" institutional decision makers. ${ }^{126}$ This of course does not happen in other scholarly traditions such as medicine, philoso-

122. This large number of outstanding comparativists operating in minor schools seems to be a common pattern also in modern day American academia.

123. See Clark, supra n. 58. On Rabel see also Kegel, "Ernst Rabel," id. at 277.

124. See Fisch, supra n. 120.

125. Compare, for a similar point, stressing the different positions in which theoretical and practical legal discourses are carried on, Dan Cohen, supra n. 63.

126. On such a role compare Rubin, "The Practice and Disclosure of Legal Scholarship," 86 Mich L. R. 1835 (1988). 
phy, physics or even economics. ${ }^{127}$ In such other disciplines the western tradition is global and may at most be opposed to the oriental one. To be sure, in such other disciplines the Western tradition is not divided, as is in the law, by the big wall between two subtraditions. ${ }^{128}$

The link between enacted law and the political process of a given country in the positivist tradition is so strong that it affects the different domain of scholarship which ought to be quite different. This is why in the modern world the political prestige of a given country may affect the chances of its legal culture to become a world leader.

\section{Reasons for the Change: Positivism and the Losses of Leadership}

The consequences just discussed of the practical and \or political aspect of legal scholarship are not enough to explain why, for example, American and not English scholarship took the lead. We must now consider factors related to the "scholarly" aspect of "legal scholarship".

Antonio Gambaro, whose efforts to understand the role of the legal scholar in the western world ${ }^{129}$ are an important contribution to comparative law literature, wrote: "After all the two phenomena always cited of diffusion of legal ideas abroad - the roman-based jus commune and the German pandectist school (to whom now you may add Law and Economics) are an exception to a constant rule that a country's legal scholarship does not copy the more efficient solutions from that of another country, even at the cost of rediscovering the wheel a century later. The language factor is only a limited explanation: if we compare legal formants we will see that scholars copy less than legislators and legislators copy less than the practically focused business lawyers. But linguistic barriers should be higher for business people than for scholars".130

The shifts in intellectual leadership which we are discussing here seem to confirm a rule that intellectual leadership has not much to do with the practical aspect of the law. It does not have much to do with rules of positive law actually produced in one country and copied in another. Rather it has to do with ways of thinking about law. We can see from the changes of leadership we have discussed that the more a legal culture takes a narrow positivistic approach, focusing on a certain particular texts or on local issues, the less likely it is to achieve leadership within the worldwide scholarly community. In modern times, in the face of orgies of statutes and statutory instru-

127. Compare, however, Buxbaum's remarks at the 1994 Meeting of the German Comparative Law Association, "Wer in dieser Welt nichts hat, frisst sich in der Nachten satt".

128. See in general Harold Berman, Law and Revolution (1983).

129. See Gambaro, "Il successo del giurista," in Foro Italiano V (1983); see also Carlo Augusto Cannata \& Antonio Gambaro, Lineamenti di storia della giurisprudenza europea (V ed. 1989).

130. Unpublished Comments to Efficiency in Legal Transplants cit. supra n. 31, March 23, 1994. 
ments, scholars in most countries feel bound to solve concrete problems of textual interpretation. They may well be interested in applying interpretative techniques and arguments learned abroad to their own law, but they are likely to be unable to do so if such techniques are too intimately linked to actual foreign provisions or issues. In such cases foreign scholarship loses interest for them. To give an example taken from the immigrant scholars, it is natural that Kessler's work on contract would not expressly refer to German provisions. Its role of cross-cultural fertilization - or of hidden legislator if we prefer to imagine a scholarly conspiracy against the democratic law making - could have been accomplished more effectively by translating the policy arguments learned in Germany into the American legal framework rather than by openly using the comparative argument. ${ }^{131}$ If the legal scholarship of one country, for example that of modern France, only uses inherently textual and local arguments, ${ }^{132}$ it may be very difficult for any scholar to translate arguments into any other textual context. We have then a cultural explanation of today's leadership of American Law in addition to the political explanation given above.

I will consider here only the waves of reception that are described in the two volumes under review, leaving aside other historical evidence that might be found. ${ }^{133}$

The enormous diffusion of the Napoleonic Code - the only instance in which a legal culture has exerted its influence via a Code can not be considered the triumph of a textual oriented positivistic legal culture. On the contrary, the Code Napoleon far from being an actual "black letter" break with the past, was a genuine product of natural law thinking, as well as of a long established European scholarly tradition. ${ }^{134}$ Its diffusion abroad and its interest for the common law jurisdictions resulted chiefly from the idea of a simple, convenient, relatively short document, imbued with the rhetoric of equality and individualism, rather than to its actual contents. ${ }^{135}$ From the moment in which French scholarship became exegetic, the decline of its prestige was already clear. Alan Watson's essay on Chancellor Kent's work is revealing from this point of view, and indeed it is easy to see that most importing countries - Italy, Holland and Louisiana offer interesting examples - felt free to tailor provisions of the code when enacting it. ${ }^{136}$ If the textual and exegetic approach was all that French culture could offer, it would become useless at the least tex-

131. This point is clearly made by Langbain, supra n. 105 .

132. See Remy, "Eloge de l'exégèse," Droits 1115 ss (1982).

133. James Gordley, who as usual is particularly interested in natural law theories, in commenting on this article pointed out at the much larger success of Grotius jurisprudential work rather than his work on Dutch law.

134. After an enormous literature that has pushed the idea of the break with the past a more recent wave of contributions seem to go in the opposite direction. See Antonio Gambaro, Codice Civile, Digesto Discipline Privatistiche (1985); Gordley, "Myths of The French Civil Code," Am. J. Comp. L. (forthcoming 1994).

135. The point is clearly made by Reimann, "Patterns," supra n. 28.

136. See for materials by Schlesinger, Baade, Damaska \& Herzog, supra n. 85, 530 ss. 
tual change of the Code. The most revealing fact, noticed in many of the contributions to Reimann's book, is that Domat and Pothier, the French civilians most influential in the common law world, were leading pre-code jurists as well as inspirers of the code. The dissatisfaction with French scholarship is clear in Italy very early and indeed explains the tremendous impact of German scholarship which was soon considered to be much more scientific. ${ }^{137}$

A slightly different pattern can be seen in the leadership, of Germany that followed. Indeed the leadership of German legal scholarship is a phenomenon completely separated from the success (or better, unsuccess) of the BGB. In the case of Germany, it is even more clear that the leadership was lost shortly after the enactment of the Code. The very reason why German scholarship was interesting and admired abroad was that it was not based on enacted (and therefore political) law. The method of reasoning based on the deduction of rules from pre-defined concepts was independent of textual enactments. There was no positive legal system in Germany when the pandectist school was flourishing. The dogmatic approach - or formalistic as we would say in this country - was an academic achievement unconcerned with whether Germany was composed of one or thirty-nine States. ${ }^{138}$ Concepts could be drawn from the Roman law (as in its original form) or from a French based Code (as in Italy) or even from English cases (as in the American Ames jurisdiction). The formalistic approach (like before the Napoleonic-style of Codification), was a genuine contribution to legal science, to "the law", as a worldwide enterprise and not a contribution to German legal science or to German law. From the moment in which the BGB was enacted, German legal culture became positivistic. Its contributions became too much concerned with texts not in force elsewhere. It was natural that such contributions slowly became uninteresting for scholars concerned with different texts.

American legal realism was the next wave of leading legal scholarship not only concerned with local issues. The previous discussion suggests why the wind shifted. First, from the time of Langdell's national law schools (and, according to Reimann, thanks to the German professorial model) ${ }^{139}$ American legal culture has never been positivistic for the simple reason that the law taught in national law schools was not the law applied in the different American States. This is indeed a feature shared by both natural law and the pandectist school.

Antiformalistic approaches, to be sure, were developed in Germany as well (and, as we know, the most important contributions of American realism were familiar to them). ${ }^{\mathbf{1 4 0}}$ But while in Germany

137. See Sacco, supra n. 9, at 260; Guarneri, "La circulation des modèles au cours des deu derniers siecles," Italian National Reports XIIIth Congress of Comparative Law (1990).

138. The best English language discussion is still Dawson, supra $\mathrm{n} .69$ at $138 \mathrm{ff}$., $432 \mathrm{ff}$. (1968).

139. See Reimann, supra n. 45.

140. The best example is Llewellyn. Even earlier, John C. Gray, The Nature and Sources of the Law (1908). See for a discussion Herget \& Wallace, cit. supra n. 66. 
the antiformalistic approach remained in the minority, in the USA it took the lead meeting the mentioned internal leadership "prerequisite" of worldwide leadership. Legal realism, as a consequence, was the next contribution to (or, if we prefer, step forward in) legal scholarship not applicable merely to local problems but ready to be applied as a method of analysis to different legal systems as well. In this enterprise of carrying legal scholarship one step forward, the contribution of the generation of migrant lawyers has been enormous. Indeed, this wave of scholars played a critical role in avoiding the risk that realism would develop in a nihilistic direction that would abdicate the role of scholars in favor of politically legitimized officials (such as nisi prius judges or New Deal bureaucrats. ${ }^{141}$ In different areas of the law and with varying degrees of influence, refugee scholars mediate between the needs of realist analysis (and of deconstruction) and the necessity that legal scholarship play a constructive role in order to maintain leadership. The reason these scholars were such successful mediators may be that they were de facto comparativists by virtue of their migration, and because they had already experienced in $\mathrm{Eu}$ rope the possible effects of both extremes in legal scholarship.

Kantorowicz gives us the best methodological example. As a civilian he was aware that law not only consists of what judges do and say. He was also extremely conscious of the role of scholarship in shaping the law. On the other hand, as a fervent antiformalist, he was perfectly sympathetic with realist conceptions. Kessler shows us the same pattern in contract law. Rabel's "third school" in conflict of law is another example, unsuccessful only because in this area Americans never had much to learn from Europe anyway. Bodenheimer in jurisprudence was able to avoid the risks of "up in the air" naturalistic theories while at the same time avoiding positivist mistakes. The same pattern may be detected in the work of others as well. ${ }^{142}$

It is noteworthy that the leadership captured by American legal culture was not lost even when the paradigm changed with the rise of law and economics. It would be beyond the scope of this review essay to enter deeply into this new area. We may just observe that law and economics is again an effort to understand the forces that are at play in the law and not in any particular legal system. It is, indeed, an approach remarkably unconcerned with positive law, ready to be applied in the analysis of any local variant of a legal system. ${ }^{43}$ And it is no surprise that it has much strengthened rather than weakened the leadership of American law. ${ }^{144}$

The influence of a legal scholar is not limited to his impact on enacted law. It is determined by his role within a given culture. From

141. On such risks see Bruce A. Ackerman, Reconstructing American Law (1983).

142. See Durham, "Edgar Bodenheimer: Conservator of Civilized Legal Culture," 127.

143. Guido Calabresi, one of the founding fathers of the Economic Analysis of Law can be considered as well a positive externality of Fascist law on American Academia.

144. See the symposium issue (Robert Cooter \& James Gordley eds.) 11 Intern'l. Rev. of L. Econ. (1991) dedicated to the diffusion of Law and Economics outside the United States. 
this point of view, we may say that there are also institutional reasons for changes of leadership in modern law internal to academic organization. American academia in general has been an extremely productive factory for the output of ideas in the recent years. Some outstanding individuals made their impact much stronger than merely influencing a piece of legislation by being powerful organizers of legal culture able to shape scholarly institutions admired everywhere. Such institutions were always inspired by Europe but were able to proceed beyond the model by getting the best of the two worlds. Langdell was influenced by the German academic organization but promoted the graduate study of law with all its advantages. ${ }^{145}$ The refugee scholars - people like Kuttner at Berkeley or Rheinstein in Chicago - were able to create impressive centers of scholarship which attracted to America legal scholars from all around the world. ${ }^{146}$ To be sure, an institute comparable to Rabel's has yet to be created in America. ${ }^{147}$ But we should consider the costs (in terms of reduced fantasy and scholarly creativity) of introducing a hierarchical academic organization on the German (or more generally European) model before regretting too much the lack of such institutes. Even if people like Homburger actively recruited their own disciples, the European system of selecting law professors on the basis of close personal links was not imported. 148 The rejection of this model was probably also a consequence of that "pragmatism, open mindedness and lack of class based rigidity"149 which may have played an important role in the change of leadership discussed in this essay.

Whether these positive attitudes of American legal scholarship are going to continue, or whether they are going to disappear in the "Impoverishment of Political Discourse" is a different question. ${ }^{150}$

\section{What's Next?}

As noted, there may be an inverse relationship between leadership in Western law and the degree of positivism and localism of a given legal culture. Leading legal ideas which exert influence are those which useful in understanding law and which are not too narrowly limited to the peculiarities of one given legal system. Such general ideas are the province of the scholarly dimension of legal discourse, while the more narrow and limited ones belong to its political or practical dimension. The former tend to circulate out of their own prestige, while the latter tend to remain static unless pushed by the strong political prestige of the legal system in which they origi-

145. See Reimann, supra n. 45.

146. This is pointed out in the papers devoted to them.

147. See, regretting this, Clark, supra n. 58.

148. See the Symposium, "Selecting Minds," 41 Am. J. Comp. L. (1993).

149. Schlesinger, "Recollections," 490.

150. From two different perspectives, very critical of the American system, Gordley, "Mere Brilliance," 38 Am. J.Comp. L. 367 (1993) and Duncan Kennedy, Legal Education and the Reproduction of Hierarchy: A Polemic Against the System (1983); see also more generally Mary Ann Glendon, Rights Talk, The Impoverishment of Political Discourse (1993). 
nate. Since these two dimensions are not easy to separate in the law - they continually overlap - the legal culture which takes leadership has to be both metapositivistic and politically acceptable. Moreover, in order to exert influence a given legal culture must be perceived by foreign scholars as leading within its own boundaries. French, German and American legal cultures met these requisites, one after the other, in modern times. The papers in the two books of this review essay are an invaluable source of evidence of the first two periods of leadership, showing that French and German legal cultures were able to penetrate the crumbling wall that divides the common law from the civil law.

A book documenting American leadership has yet to be written. I hope in this review essay to have been able to offer at least a prima facie case for it. As in pluralistic politics, also in the law, leadership is difficult to acquire and easy to lose. In the modern post cold war Western world it is not likely that the American political leadership will be enough to guarantee the leadership abroad of its legal culture without a new wave of deprovincialization. Much of the struggle for intellectual leadership among lawyers will therefore be linked to the quality of the scholarly products that each culture will be able to produce. Whether the most modern waves of American academic writing - from Critical Legal Studies to Gender and Race legal studies will be able to offer real contributions to legal thought outside the U.S., or whether these efforts will remain too closely linked to political or institutional contingencies uninteresting worldwide, remains to be seen. ${ }^{151} \mathrm{It}$ is a fact, however, that American academia is becoming more and more turned in upon itself and that the generation of great comparativists that was given to this country by the twentieth century tragedy has yet to be replaced. This self sufficient attitude may produce new changes of leadership given that the "willingness to use individual (American) states as legislative laboratories to try out new ideas"152 is not likely to be enough to guarantee American culture against parochialism in the era of worldwide integration. Examples, sometimes have to be taken from abroad.

One may hope however that in the future, it will not make sense to ask from which country a scholarly contribution comes. Scholarship in the law, as in all other disciplines, cannot afford to be parochial if it is to survive.

151. Donna Artz, in her paper notices for example how, surprisingly, Kirchhaimer - even though part of the Frankfurt school - has been totally ignored by the American critical scholarship.

152. Schlesinger, "Recollections," 490. 